\title{
ANALISIS KESALAHAN SISWA SMP DALAM MENYELESAIKAN SOAL BANGUN RUANG
}

\author{
Ratih Ayu Utami \\ Jurusan Matematika, Program Studi Pendidikan Matematika, FMIPA, Universitas Negeri Surabaya, \\ email: ratihutami@mhs.unesa.ac.id
}

\begin{abstract}
Abstrak
Penelitian ini bertujuan untuk: (1) mendeskripsikan letak kesalahan siswa dalam menyelesaikan soal bangun ruang, (2) mendeskripsikan jenis kesalahan siswa dalam menyelesaikan soal bangun ruang, dan (3) mendeskripsikan faktor penyebab kesalahan siswa dalam menyelesaikan soal bangun ruang. Penelitian ini merupakana penelitian kualitatif dengan menggunakan metode tes dan wawancara dan dilakukan di SMP Negeri 21 Surabaya. Pemilihan subjek berdasakan kriteria yaitu siswa dengan banyak melakukan kesalahan pada indikator letak dan jenis kesalahan, variasi kesalahan, dan keterbukaan serta kelancaran subjek untuk berkomunikasi selama proses wawancara berlangsung.
\end{abstract}

Kata Kunci: kesalahan, subjek, soal bangun ruang.

\section{Abstract}

This study aims to: (1) describe the location of the students' mistakes in solving geometrical problems, (2) to describe the students' mistakes in solving geometrical problems, and (3) to describe the factors that cause students' errors in solving geometric problems. This research is a qualitative study using test and interview methods and was conducted at SMP Negeri 21 Surabaya. Selection of subjects based on criteria, namely students who made many mistakes on indicators of the location and type of error, variation of errors, openness and fluency of the subject to communicate during the interview process.

Keywords: mistakes, subject, geometric problems.

\section{PENDAHULUAN}

Soal matematika diberikan kepada siswa sebagai alat evaluasi untuk mengukur kemampuan matematika yang dimiliki siswa setelah menerima suatu materi. Dari hasil evaluasi, dapat diketahui sejauh mana keberhasilan proses belajar mengajar dan letak kesalahan siswa. Untuk meningkatkan hasil belajar matematika, maka sumber kesalahan yang dilakukan oleh siswa harus segera diatasi karena siswa akan mengalami kesulitan jika kesalahan sebelumnya tidak segera diperbaiki terutama pada soal yang memiliki karakteristik yang sama dengan soal dimana siswa sering melakukan kesalahan.

Pemecahan masalah dalam matematika sekolah biasanya diwujudkan melalui soal cerita. Dalam penyelesaian soal cerita terlebih dahulu siswa harus dapat memahami isi soal cerita tersebut setelah itu menarik kesimpulan objek-objek yang harus diselesaikan dan memisalkannya dengan simbol-simbol matematika, sampai pada tahap akhir yaitu penyelesaian (Rindyana: 2012).

Dalam pembelajaran matematika memerlukan tahaptahap yang hirarkis, yakni bentuk belajar yang terstruktur dan terencana berdasarkan pada pengetahuan dan latihan sebelumnya, yang menjadi dasar untuk mempelajari materi selanjutnya. Namun, umumnya siswa kurang memahami dan menguasai hal tersebut yang berakibat timbulnya kesalahan siswa dalam menyelesaikan soalsoal matematika. Menurut Rosmaryati (2016), pada dasarnya kesalahan siswa dalam menyelesaikan soal matematika antara lain disebabkan kurangnya penguasaan konsep matematika. Kesalahan siswa yang lain dalam menyelesaikan soal matematika yaitu kurangnya ketelitian dalam menghitung. Siswa seringkali salah dalam menghitung suatu bentuk perkalian, pembagian, penjumlahan dan pengurangan bilangan.

Faktor-faktor yang mempengaruhi siswa melakukan kesalahan ketika menyelesaikan soal matematika dapat dipengaruhi oleh dua faktor yaitu faktor internal dan faktor eksternal.Menurut Novitasari (2015), faktor internal meliputi kondisi kognisi, kondisi fisik atau jasmani, lupa, tidak paham terhadap permintaan soal, dan tidak teliti dalam menjawab. Sedangkan yang merupakan faktor eksternal meliputikesalahan informasi dari guru, karakteristik materi, dan fasilitas belajar. 
Bangun ruang merupakan salah satu materi yang diajarkan di SMP kelas VIII. Menurut kementerian pendidikan dan kebudayaan dalam laporan hasil ujian nasional tahun 2014, daya serap matematika SMP/MTs materi unsur-unsur/sifat-sifat bangun ruang sisi datar (dimensi tiga) menunjukkan adanya penurunan yang cukup drastis dari tahun 2012 ke 2013 yaitu dari $72.90 \%$ ke $50.92 \%$ meskipun terjadi peningkatan pada tahun berikutnya yaitu tahun 2014 ke $60.58 \%$. Hal ini menunjukkan bahwa siswa masih mengalami kesulitan terhadap materi bangun ruang sisi datar.

Selain itu, berdasarkan laporan pemanfaatan hasil ujian nasional tahun pelajaran 2015/2016 provinsi Jawa Timur, persentase penguasaan materi bangun ruang sisi datar sebesar $50.09 \%$ pada tingkat provinsi dan $47.19 \%$ pada tingkat nasional. Hal ini menunjukkan bahwa tingkat penguasaan materi geometri dan pengukuran siswa provinsi Jawa Timur masih rendah. Untuk itu perlu dilakukan analisis terhadap kesalahan-kesalahan yang sering dilakukan oleh siswa ketika menyelesaikan soalsoal bangun ruang sisi datar.

Berdasarkan Pusat Penilaian Pendidikan Kementerian Pendidikan dan Kebudayaan, persentase siswa yang menjawab benar sebesar $48,70 \%$ untuk tingkat kota Surabaya dan $47,88 \%$ untuk tingkat propinsi Jawa Timur untuk materi geometri dan pengukuran. Persentase tersebut lebih rendah dibandingkan dengan tiga materi lainnya.

Berdasarkan uraian di atas, peneliti tertarik untuk melakukan penelitian dengan judul Analisis Kesalahan Siswa SMP dalam Menyelesaikan Soal Bangun Ruang.

Soal cerita merupakan bentuk modifikasi dari soalsoal hitungan yang berkaitan dengan kenyataan yang ada dilingkungan siswa. Syafik (dalam Ramadzani: 2014) berpendapat soal cerita matematika merupakan suatu bentuk soal yang permasalahannya dijabarkan dalam bentuk cerita, dan dalam penyelesaiannya diperlukan suatu keterampilan untuk merumuskan masalah yang terdapat di dalamnya. Sedangkan menurut Ramadzani (2014) mendefinisikan soal cerita sebagai soal yang disampaikan dengan menggunakan bahasa verbal dan berkaitan dengan kehidupan sehari-hari yang dapat diubah ke dalam kalimat matematika dan dapat diselesaikan menggunakan konsep matematika.

Brown (2016) mengatakan analisis kesalahan adalah jenis penelitian diagnostik yang dapat membantu guru menentukan jenis kesalahan yang dibuat oleh siswa dan mengapa. Howell (dalam Peogoeh: 2016) menyatakan bahwa analisis kesalahan melibatkan analisis pola kesalahan untuk mengidentifikasi kesulitan siswa dalam hal fakta, konsep, strategi dan prosedur. Berdasarkan uraian di atas maka analisis kesalahan adalah penyelidikan terhadap penyimpangan yang dilakukan oleh siswa dalam menyelesaikan soal.

Letak kesalahan adalah kesalahan dalam menentukan langkah-langkah penyelesaian soal. Letak kesalahan dalam penelitian ini adalah:

1. Kesalahan dalam memahami soal, siswa dikatakan melakukan kesalahan dalam memahami soal apabila siswa tidak mampu memahami maksud dari soal, siswa tidak mampu menentukan apa yang diketahui dan apa yang ditanyakan dalam soal atau siswa mampu memahami soal tetapi belum menangkap informasi yang terkandung dalam pertanyaan, sehingga siswa tidak dapat mengerjakan soal dan menemukan penyelesaiannya.

2. Kesalahan dalam menggunakan rumus, siswa dikatakan melakukan kesalahan dalam menggunakan rumus apabila siswa tidak mampu mengidentifikasi atau menentukan rumus apa yang akan digunakan atau yang diperlukan dalam menyelesaikan soal.

3. Kesalahan operasi, siswa dikatakan melakukan kesalahan operasi apabila siswa salah dalam melakukan prosedur atau langkah-langkah yang digunakan untuk menyelesaikan soal.

4. Kesalahan dalam menyimpulkan, siswa dikatakan melakukan kesalahan dalam menyimpulkan apabila siswa tidak memperhatikan kembali apa yang ditanyakan soal dan tidak membuat kesimpulan dari hasil perhitungan.

Jenis-jenis kesalahan dalam penelitian ini adalah:

1. Kesalahan konsep, adalah kesalahan dalam memahami konsep matematika yang menjadi prasyarat maupun konsep yang diajarkan. Indikatornya adalah salah dalam memahami makna soal dan salah dalam menerjemahkan soal ke dalam bentuk matematika.

2. Kesalahan prinsip, adalah kesalahan dalam menggunakan rumus-rumus atau aturan-aturan matematika. Indikatornya adalah salah dalam menggunakan rumus-rumus atau aturan-aturan matematika.

3. Kesalahan pengoperasian, adalah kesalahan dalam melakukan perhitungan atau operasi. Indikatornya adalah salah dalam menggunakan aturan operasi dengan benar.

4. Kesalahan dalam menarik kesimpulan, adalah kesalahan dalam menuliskan kesimpulan dari persoalan yang telah diselesaikan, tidak menuliskan kesimpulan maupun kesimpulan yang dibuat tidak menjawab pertanyaan yang diberikan. Indikatornya adalah tidak dapat membuat kesimpulan dari soal yang telah diselesaikan dam salah dalam menuliskan kesimpulan. 
Faktor penyebab kesalahan siswa dalam menyelesaikan soal akan dibatasi hanya pada faktor internal saja. Faktor internal dalam penelitian ini adalah sesuatu yang menjadi penyebab terjadinya kesalahan ditinjau dari ketidakmampuan siswa dalam memahami konsep maupun prosedur yang ada. Penyebab kesalahan siswa dapat diketahui melalui kegiatan wawancara. Beberapa penyebab kesalahan siswa antara lain: lupa, kurang teliti, tidak cermat melakukan perhitungan, kurang memahami kosep, dan tidak dapat menghubungkan soal dengan materi yang telah diperoleh.

\section{METODE}

Penelitian ini menggunakan penelitian kualitatif. Penelitian kualitatif merupakan jenis penelitian yang bersifat deskriptif analitik karena data yang diperoleh tidak dituangkan dalam bentuk bilangan statistik, namun dalam bentuk kata-kata atau gambar-gambar.

Penelitian ini bertujuan untuk mendeskripsikan letak kesalahan siswa, jenis kesalahan siswa dan faktor-faktor apa saja yang menyababkan kesalahan siswa selama menyelesaikan soal. Penelitian dilakukan kepada siswa kelas IX SMP Negeri 21 Surabaya.

Instrumen penelitian ini berupa tes tulis dan wawancara. Tes diberikan kepada siswa setelah berdiskusi terlebih dahulu kepada guru matematika yang bersangkutan. Setelah melakukan tes, peneliti memeriksa jawaban siswa dan menentukan 3 subjek yang kemudian dilakukan wawancara untuk mengetahui faktor penyebab kesalahan yang dilakukan oleh siswa. Dari tes dan wawancara yang diberikan oleh siswa, peneliti mendeskripsikan letak kesalahan, jenis kesalahan, dan faktor penyebab kesalahan yang dilakukan oleh siswa dalam menyelesaikan soal bangun ruang.

\section{HASIL DAN PEMBAHASAN}

Tes diikuti oleh 35 siswa dari 38 siswa. Tiga siswa tidak mengikuti tes karena berhalangan hadir. Soal tes sebanyak 4 butir soal uraian dengan waktu pengerjaan 60 menit yang dikerjakan secara individu. Setelah siswa selesai mengerjakan soal yang diberikan, peneliti memeriksa jawaban siswa dan mengecek kesalahan yang dilakukan oleh siswa. Kesalahan yang dicek berupa letak kesalahan dan jenis kesalahan yang dilakukan oleh siswa.

Pemilihan subjek dipilih dengan kriteria paling banyak melakukan kesalahan, jenis kesalahan yang bervariasi, serta kemampuan komunikasi yang baik. Dengan kriteria tersebut maka dipilihlah 3 subjek yang memenuhi sebagai berikut:

Tabel 1 Subjek Penelitian

\begin{tabular}{|l|l|l|l|}
\hline No. & Nama & $\begin{array}{l}\text { Jumlah } \\
\text { Kesalahan }\end{array}$ & Kode \\
\hline
\end{tabular}

\begin{tabular}{|l|l|l|l|}
\hline 1. & GAP & 26 & SP1 \\
\hline 2. & ARE & 22 & SP2 \\
\hline 3. & MYR & 12 & SP3 \\
\hline
\end{tabular}

Berikut rincian subjek yang terpilih.

1. GAP adalah subjek penelitian pertama (SP1). Pada soal nomor 1, subjek melakukan kesalahan pada penggunaan rumus. Subjek tidak memperhatikan dengan seksama apa yang dimaksud dari soal. Selain itu subjek juga melakukan kesalahan penulisan pada hasil akhir yaitu pada penulisan tanda koma pada hasil perkalian.

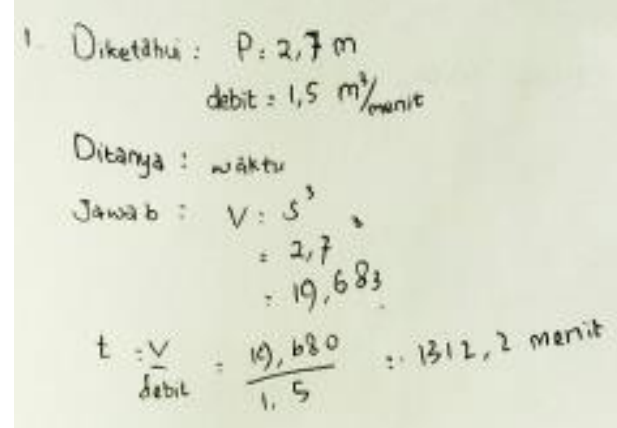

Gambar 1 Jawaban SP1 pada soal nomor 1

1. Letak kesalahan

a. Kesalahan dalam memahami soal, yaitu subjek belum memahami soal dengan baik, tidak memahami makna dari soal, tidak lengkap dalam menuliskan diketahui dan yang ditanyakan dalam soal.

b. Kesalahan dalam menggunakan rumus, yaitu subjek salah menggunakan rumus yang tepat yang diakibatkan oleh belum memahami soal yang diberikan.

c. Kesalahan pengoperasian, yaitu subjek salah dalam melakukan operasi pembagian.

d. Kesalahan dalam menyimpulkan, yaitu subjek salah menuliskan jawaban akhir akibat dari kesalahan terdahulu.

2. Jenis kesalahan

a. Kesalahan konsep, yaitu subjek tidak memahami soal dengan baik.

b. Kesalahan prinsip, yaitu subjek salah dalam menentukan rumus yang tepat.

c. Kesalahan operasi, yaitu subjek salah melakukan operasi pembagian.

d. Kesalahan dalam menyimpulkan, yaitu subjek salah dalam menyimpulkan disebabkan karena kesalahan terdahulu.

3. Faktor penyebab kesalahan

a. Subjek kurang memahami soal.

b. Subjek tidak memahami makna soal.

c. Subjek salah menentukan rumus yang tepat. 


\section{ANALISIS KESALAHAN SISWA SMP...}

d. Subjek tidak dapat menggunakan aturan operasi pembagian dengan tepat.

e. Subjek tidak teliti dalam menyelesaikan soal.

Pada soal nomor 2, subjek melakukan kesalahan pada tahap perhitungan sehingga subjek salah menuliskan jawaban akhir yang tepat.

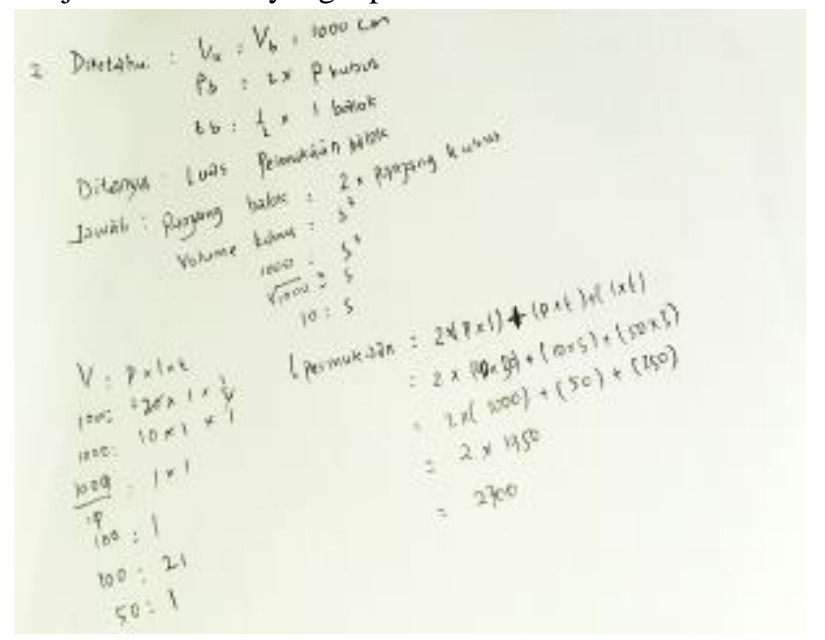

Gambar 2 Jawaban SP1 pada soal nomor 2

1. Letak kesalahan

a. Kesalahan dalam memahami soal, yaitu subjek tidak dapat mengubah kalimat soal ke dalam kalimat matematika.

b. Kesalahan pengoperasian, yaitu subjek salah dalam melakukan operasi perkalian.

c. Kesalahan dalam menyimpulkan, yaitu subjek salah menuliskan jawaban akhir.

2. Jenis kesalahan

a. Kesalahan konsep, yaitu subjek tidak dapat mengubah kalimat soal menjadi kalimat matematika.

b. Kesalahan operasi, yaitu subjek salah melakukan operasi perkalian bentuk aljabar.

c. Kesalahan dalam menyimpulkan, yaitu subjek salah dalam mnuliskan jawaban akhir.

3. Penyebab kesalahan

a. Subjek tidak dapat mengubah kalimat dalam soal ke dalam bentuk kalimat matematika.

b. Subjek belum memahami konsep aljabar.

c. Subjek masih bingung antara perkalian dua variabel dan penjumlahan dua variabel.

d. Subjek salah memasukkan angka ke dalam rumus disebabkan oleh kesalahan sebelumnya.

e. Subjek tidak teliti dalam menyelesaikan soal.

Pada soal nomor 3, subjek melakukan kesalahan pada penggunaan rumus. Subjek salah menggunakan rumus yang tepat disebabkan subjek belum memahami maksud soal.

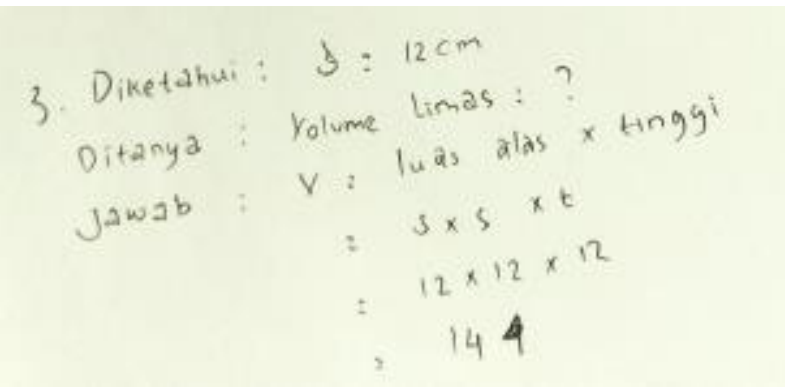

Gambar 3 Jawaban SP1 pada soal nomor 3

1. Letak kesalahan

a. Kesalahan dalam memahami soal, yaitu subjek belum memahami maksud dan makna soal.

b. Kesalahan menggunakan rumus, yaitu subjek tidak dapat menentukan rumus yang tepat untuk menyelesaikan soal.

c. Kesalahan dalam menyimpulkan, yaitu subjek salah dalam menuliskan jawaban akhir.

2. Jenis kesalahan

a. Kesalahan konsep, yaitu subjek tidak dapat memahami maksud soal.

b. Kesalahan prinsip, yaitu subjek tidak dapat menentukan rumus yang tepat.

3. Penyebab kesalahan

a. Subjek tidak dapat memahami maksud dari soal.

b. Subjek tidak dapat menentukan rumus yang tepat yang digunakan untuk menyelesaikan soal.

c. Subjek asal dalam menuliskan rumus.

Pada soal nomor 4, subjek tidak memperhatikan satuan ang digunakan sehingga hasil yang diinginkan tidak sesuai. Subjek juga tidak menyelesaikan pekerjaannya sehingga tidak dapat membuat kesimpulan.

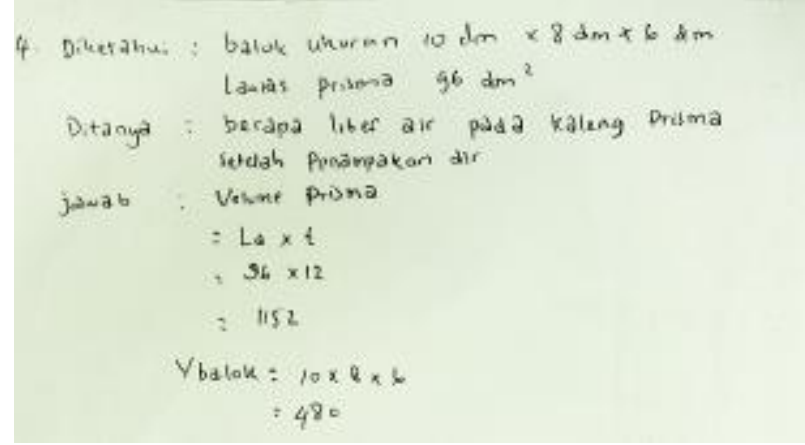

Gambar 4 Jawaban SP1 pada soal nomor 4

1. Letak kesalahan 
a. Kesalahan dalam pengoperasian, yaitu subjek lupa mengkonversikan satuan yang digunakan.

b. Kesalahan dalam menyimpulkan, yaitu subjek salah dalam menuliskan jawaban akhir.

2. Jenis kesalahan

a. Kesalahan konsep, yaitu subjek tidak dapat memahami soal dengan baik.

b. Kesalahan operasi, yaitu subjek tidak mengkonversikan satuan yang digunakan.

c. Kesalahan dalam menyimpulkan, yaitu subjek salah dalam menuliskan jawaban dikarenakan subjek salah memasukkan angka yang benar ke dalam rumus, subjek tidak menyelesaikan jawaban akhir.

3. Penyebab kesalahan

a. Subjek kurang memahami soal.

b. Subjek tidak teliti dalam menentukan satuan yang digunakan.

c. Subjek lupa mengubah satuan yang digunakan.

d. Subjek tidak dapat menyelesaikan jawaban karena waktu yang mepet.

2. ARE adalah subjek penelitian kedua (SP2). Pada soal nomor 1, subjek melakukan kesalahan pada penulisan satuan yang diketahui, subjek kurang lengkap menuliskannya. Selain itu, subjek salah dalam menggunakan rumus yang tepat dan melakukan kesalahan pada operasi hitung.

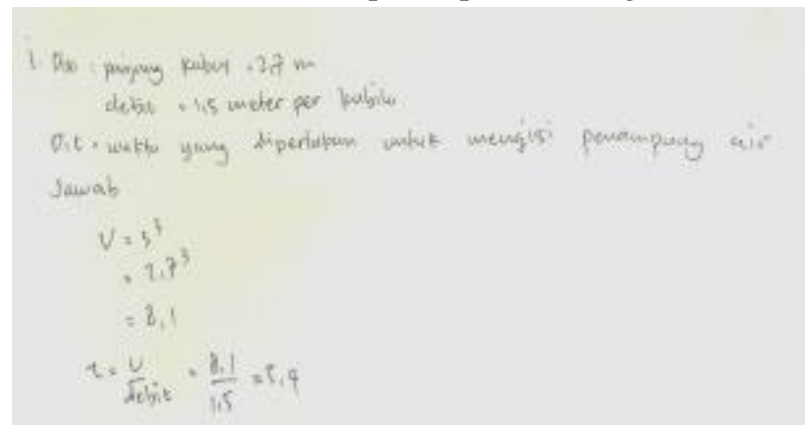

Gambar 5 Jawaban SP2 pada soal nomor 1

1. Letak kesalahan

a. Kesalahan memahami soal, yaitu subjek tidak dapat memahami maksud dari soal, tidak dapat mengetahui apa yang diketahui dan ditanyakan dari soal.

b. Kesalahan dalam menggunakan rumus, yaitu subjek salah dalam mengidentifikasi rumus yang tepat untuk menyelesaikan soal.

c. Kesalahan operasi, yaitu subjek salah dalam melakukan pengoperasian. d. Kesalahan dalam menyimpulkan, yaitu subjek salah dalam menuliskan jawaban akhir.

2. Jenis kesalahan

a. Kesalahan konsep, yaitu subjek tidak dapat menerjemahkan soal ke dalam bentuk matematika, subjek tidak dapat menggunakan simbol-simbol matematika.

b. Kesalahan prinsip, yaitu subjek salah dalam menggunakan rumus yang tepat untuk menyelesaikan soal.

c. Kesalahan pengoperasian, yaitu subjek salah dalam melakukan operasi hitung.

d. Kesalahan menarik kesimpulan, yaitu subjek salah dalam menuliskan jawaban akhir.

3. Penyebab kesalahan

a. Subjek belum memahami maksud dari soal yang diberikan.

b. Subjek tidak teliti.

c. Subjek salah dalam menggunakan rumus yang tepat untuk menyelesaikan soal.

d. Subjek salah dalam melakukan operasi.

Pada soal nomor 3, subjek melakukan kesalahan pada apa yang ditanyakan dan salah menggunakan rumus. Selain itu, subjek juga tidak dapat mengubah informasi soal ke dalam kalimat matematika dan simbol-simbol matematika.

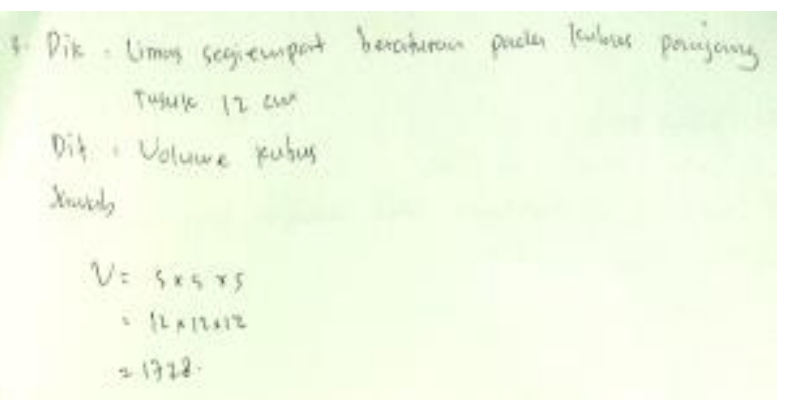

Gambar 6 Jawaban SP2 pada soal nomor 3

1. Letak kesalahan

a. Kesalahan dalam memahami soal, yaitu subjek kurang memahami maksud dari soal, tidak dapat mengubah informasi soal ke dalam kalimat matematika dan simbolsimbol matematika.

b. Kesalahan dalam menggunakan rumus, yaitu siswa salah menggunakan rumus yang tepat.

c. Kesalahan dalam menyimpulkan, yaitu subjek salah menuliskan jawaban akhir.

2. Jenis kesalahan

a. Kesalahan konsep, yaitu subjek kurang memahami maksud soal. 
b. Kesalahan prinsip, yaitu subjek tidak menggunakan rumus yang tepat.

c. Kesalahan dalam menyimpulkan, yaitu subjek salah menuliskan jawaban akhir.

3. Penyebab kesalahan

a. Subjek masih belum memahami apa yang dimaksud dari soal.

b. Subjek tidak dapat mengolah informasi yang ada di soal ke dalam kalimat matematika.

c. Subjek tidak tahu apa yang ditanyakan dalam soal.

d. Subjek salah menggunakan rumus yang tepat.

e. Subjek salah menuliskan jawaban akhir yang disebabkan oleh kesalahan sebelumnya yaitu salah dalam menggunakan rumus yang tepat.

Pada soal nomor 4, subjek tidak memperhatikan satuan ang digunakan sehingga hasil yang diinginkan tidak sesuai. Subjek juga tidak menyelesaikan pekerjaannya sehingga tidak dapat membuat kesimpulan.

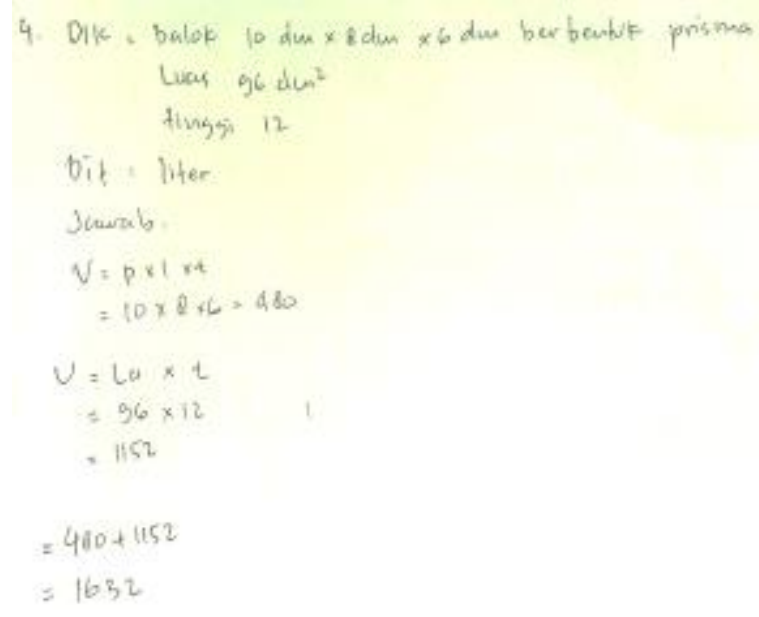

Gambar \& Jawaban SP2 pada soal nomor 4

\section{Letak kesalahan}

a. Kesalahan dalam memahami soal, yaitu siswa kurang memahami soal.

b. Kesalahan pengoperasian, yaitu siswa tidak melakukan konversi satuan yang tepat.

c. Kesalahan dalam menyimpulkan, yaitu siswa salah menuliskan jawaban akhir yang disebabkan oleh kesalahan sebelumnya yaitu kesalahan pengoperasian.

2. Jenis kesalahan

a. Kesalahan konsep, yaitu subjek masih kurang memahami soal yang diberikan.

b. Kesalahan operasi, yaitu subjek tidak mengkonversikan satuan yang diinginkan. c. Kesalahan dalam menyimpulkan, yaitu subjek salah dalam meuliskan jawaban akhir yang disebabkan subjek tidak mengkonversikan satuan terlebih dahulu.

\section{Penyebab kesalahan}

a. Subjek kurang memahami maksud soal.

b. Subjek tidak teliti dalam menyelesaikan soal.

c. Subjek tidak teliti dalam penggunakan satuan.

3. MYR adalah subjek penelitian ketiga (SP3). Pada soal nomor 1, subjek melakukan kesalahan pada penggunaan rumus. Subjek kurang tepat menggunakan rumus, subjek jjuga melakukan kessalahan pada operasi hitung yaitu padda penempatan tanda koma. Selain itu subjek tidak dapat menyelesaikan soal nomor satu.

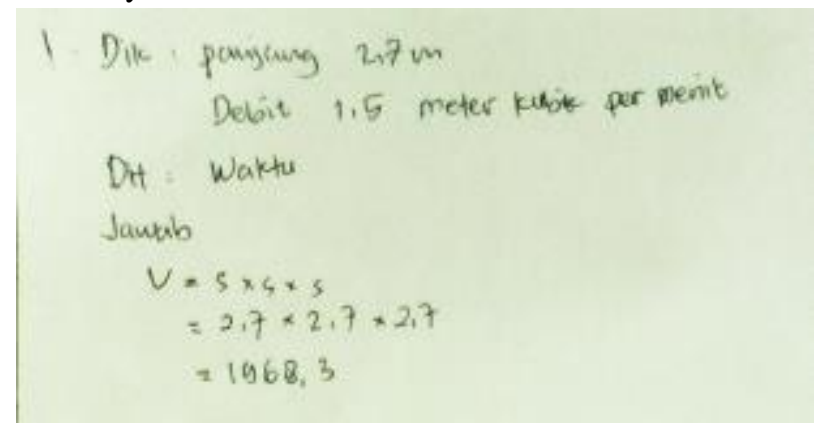

Gambar 8 Jawaban SP3 pada soal nomor 1

1. Letak kesalahan

a. Kesalahan dalam memahami soal, yaitu subjek belum memahami maksud soal.

b. Kesalahan dalam menggunakan rumus, yaitu subjek salah menggunakan rumus yang tepat.

c. Kesalahan dalam pengoperasian, yaitu subjek salah dalam penempatan koma pada hasil perkalian.

d. Kesalahan dalam menyimpulkan, yaitu subjek tidak dapat menuliskan jawaban akhir dikarenakan kesalahan pada tahap sebelumnya.

2. Jenis kesalahan

a. Kesalahan konsep, yaitu subjek tidak memahami soal.

b. Kesalahan prinsip, yaitu subjek tidak dapat merencanakan penyelesaian yang tepat dan salah menggunakan rumus.

c. Kesalahan operasi, yaitu subjek tidak memahami penempatan tanda kome pada hasil perkalian dengan benar.

d. Kesalahan dalam menyimpulkan, yaitu subjek tidak dapat menuliskan jawaban akhir 
yang disebabkan kesalahan pada tahap sebelumnya.

3. Penyebab kesalahan

a. Subjek belum memahami maksud dari soal.

b. Subjek tidak dapat merencanakan penyelesaian yang benar.

c. Subjek tidak dapat menggunakan rumus yang tepat.

d. Subjek tidak memahami konsep operasi pada penempatan tanda koma pada hasil perkalian.

Pada soal nomor 2, subjek melakukan kesalahan pada operasi hitung.

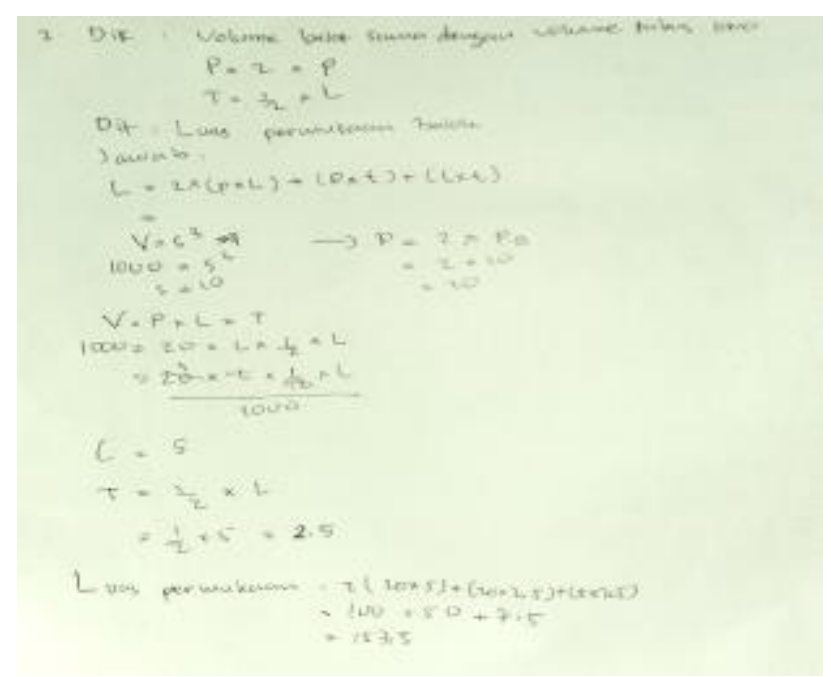

Gambar 9 Jawaban SP3 pada soal nomor 2

1. Letak kesalahan

a. Kesalahan dalam pengoperasian, yaitu subjek salah dalam melakukan perhitungan.

b. Kesalahan dalam menyimpulkan, yaitu subjek salah menuliskan jawaban akhir dikarenakan salah dalam perhitungan sebelumnya.

2. Jenis kesalahan

a. Kesalahan operasi, yaitu subjek tidak teliti dan dalam melakukan perhitungan.

b. Kesalahan dalam menyimpulkan, yaitu subjek tidak dapat menuliskan jawaban akhir yang disebabkan kesalahan pada tahap sebelumnya.

3. Penyebab kesalahan

a. Subjek tidak teliti dalam mengerjakan soal.

b. Subjek tergesa-gesa dalam menyyelesaikan soal.

c. Subjek tidak memeriksa kembali jawabannya.

\section{PENUTUP}

\section{Simpulan}

Dari hasil penelitian, dapat disimpulkan bahwa siswa melakukan kesalahan dengan letak kesalahan pada memahami soal, menggunakan rumus, pengoperasian, dan penulisan jawaban akhir. Sedangkan jenis kesalahan yang dilakukan yaitu kesalahan konsep, kesalahan prinsip, kesalahan operasi, kesalahan dalam menyimpulkan. Berikut pemaparan letak kesalahan, jenis kesalahan, dan penyebab kesalahan yang dilakukan siswa dalam menyelesaikan soal bangun ruang:

1. Letak kesalahan

a. Kesalahan memahami soal

1) Subjek tidak memahami maksud dari soal.

2) Subjek salah menuliskan apa yang diketahui dan ditanyakan.

3) Subjek menuliskan apa yang diketahui dengan simbol-simbol yang dibuat sendiri.

b. Kesalahan menggunkan rumus

1) Subjek tidak dapat merencanakan penyelesaian.

2) Subjek salah menngunakan rumus yang tepat.

c. Kesalahan pengoperasian

1) Subjek salah dalam melakukan perhitungan.

2) Subjek tidak dapat melakukan operasi dengan benar.

d. Kesalahan dalam menyimpulkan

1) Subjek tidak dapat menuliskan jawaban akhir yang benar.

2. Jenis kesalahan

a. Kesalahan konsep

1) Subjek tidak dapat memahami maksud dan tujuan dari soal.

2) Subjek salah menggunakan simbol-simbol dalam matematika.

b. Kesalahan prinsip

1) Subjek salah dalam menggunakan rumus yang tepat.

c. Kesalahan pengoperasian

1) Subjek tidak dapat menngunakan aturan operasi atau perhitungan dengan benar.

3. Penyebab kesalahan

a. Kesalahan memahami soal

1) Subjek mengalami kesulitan dalam memahami beberapa kata dalam soal. Artinya subjek tidak dapat menafsirkan maksud atau makna dari soal. Dari situasi tersebut, subjek masih kurang dalam penguasaan bahasa sehingga subjek tidak dapat menangkap maksud dari soal. 
2) Subjek tidak dapat memahami apa yang diketahui dari soal.

b. Kesalahan menggunakan rumus

1) Subjek tidak dapat merencanakan penyelesaian dengan benar.

c. Kesalahan operasi

1) Subjek salah dalam melakukan prosedur yang tepat.

2) Subjek tidak memahami konsep aljabar.

3) Subjek tidak memahami aturan perkalian pada bentuk pangkat dengan benar.

4) Subjek tidak memahami aturan penempatan koma pada hasil perkalian.

5) Subjek tidak teliti dalam melakukan perhitungan.

6) Subjek tergesa-gesa mengerjakan soal.

d. Kesalahan dalam menyimpulkan

1) Subjek tidak dapat menyelesaikan soal.

2) Subjek salah menuliskan jawaban akhir dikarenakan kesalahan pada tahap sebelumnya.

3) Subjek tergesa-gesa dalam menuliskan jawaban akhir.

\section{Saran}

Peneliti menyarankan agar penelitian yang serupa dapat dikembangkan lagi dari segi keberagaman letak, jenis, dan penyebab kesalahan yang dilakukan oleh siswa.

\section{DAFTAR PUSTAKA}

Arini, Silvia Dessy. 2016. Analisis Kesalahan Siswa dalam Menyelesaikan Soal Persamaan Garis Lurus. Skripsi Tidak Dipublikasikan. Universitas Negeri Surabaya.

Asyari, Hasyim. 2015. Analisis Kesalahan Siswa SMP dalam menyelesaikan Soal Operasi Pecahan Bentuk Aljabar. Tesis tidak dipublikasikan. Universitas Negeri Surabaya.

As'ari, Abdur Rahman dkk. 2014. Buku Pegangan Siswa Matematika SMP Kelas 8 Semester 2 Kurikulum 2013. Jakarta: Kementerian Pendidikan dan Kebudayaan.

Brown, Janice dan Skow, Kim. 2016. Mathematics: Identifying and Addressing Student Errors. (iris.peabody.vanderbilt.edu or iriscenter.com diakses pada tanggal 5 November 2016).

Dupe, Melkianus James. 2015. Analisis Kesalahan Siswa SMP dalam Menyelesaikan Soal Cerita Bangun Datar. Tesis tidak dipublikasikan. Universitas Negeri Surabaya.
Kemdikbud. (2014). Laporan Hasil ujian Nasional Tahun 2014. (http://penilaian.kemdikbud.go.id/perpustakaan_penil aian/uploaded/pdf/9a95ad3bc2ceb8a6dd05a7368faa0 302.pdf diakses pada tanggal 5 November 2016)

Novitasari, Nur Fajrina. 2015. Analisis Kesalahan Siswa SMP dalam Memecahkan Masalah Matematika pada Materi Garis Singgung Lingkaran. Skripsi Tidak Dipublikasikan. Universitas Negeri Surabaya.

Poegoeh, Yosianarti. 2016. Analisis Kesalahan Siswa SMP dalam Menyelesaikan Soal Pecahan Bentuk Aljabar. Tesis tidak dipublikasikan. Universitas Negeri Surabaya.

Polya, G. 1973. How to Solve It. New Jersey: Pricenton Univercity Press.

Ramadzani, Richa Alfiatun. 2014. Profil Peserta Didik SMPKelas VII dalam Menyelesaikan Soal Cerita Materi Pecahan Ditinjau dari Kemampuan Matematika. Skripsi tidak dipublikasikan. Universitas Negeri Surabaya.

Rosmaryati, Yenny Dian. 2015. Analisis Kesalahan Siswa SMP Negeri 3 Surabaya dalam Menyelesaikan Soal Operasi Hitung Pecahan Bnetuk Aljabar. Tesis tidak dipublikasikan. Universitas Negeri Surabaya.

Setiyawati, Indra. (2011). Identifikasi kesalahan dalam Menyelesaikan Soal Cerita Materi Pelajaran Segitiga dan Segiempat Siswa Kelas VII SMP N 5 Depok Sleman Yogyakarta Tahun Ajaran 2010/1011. Universitas Negeri Yogyakarta. (http://eprints.uny.ac.id/1892/1/Skripsi_Indra_Setiya wati.pdf diakses pada tanggal 5 November 2016)

Suharjana, Agus. 2008. Pengenalan Bangun Ruang dan Sifat-Sifatnya di SD. Yogyakarta: Pusat Pengembangan dan Pemberdayaan Pendidik dan Tenaga Kependidikan Matematika. http://repositori.perpustakaan.kemdikbud.go.id/689/1/ 9-Pengenalan-bangun-ruang-dan-sifat2nya.pdf diakses pada tanggal 20 Juli 2017)

Sukirman. Kesalahan. (online), (http://karya-ilmiah-umac-id/index.php/mathematicarticle/view/5514 diakses pada tanggal 5 November 2016).

Umam, Muhammad Dliwaul. 2014. Analisis Kesalahan Siswa dalam Menyelesaikan Soal Cerita Matematika Materi Operasi Hitung Pecahan. Skripsi tidak dipublikasikan. Universitas Negeri Surabaya.

UNESA. 2000. Pedoman Penulisan Artikel Jurnal, Surabaya: Lembaga Penelitian Universitas Negeri Surabaya. 
White, Allan L. 2010. Numeracy, Literacy and Newman's Error Analysis. Journal of Science and Mathematics Education in Southeast Asia. Vol 33 No 2, 129-148. University of Western Sydney.

White, Allan L. 2005. Active Mathematics In Classrooms Finding Out Why Children Make Mistake And Then Doing Something To Help Them. University of Western Sydney. Square One, Vol 15, No.4, December 2005. (http://www.curricilumsupport.education.nsw.gov.au/ primary.mathematics/assets/pdf/sqone.pdf. diakses pada tanggal 5 November 2016).

Wijaya, A. A . 2013. Analisis Kesalahan Siswa dalam Menyelesaikan Soal Cerita Sitem Persamaan Linier Dua Variabel, MATHEdunesa, 2.1 ejournal.unesa.ac.id. ISO 690. 